\title{
Detection by polymerase chain reaction of genes encoding aminoglycoside-modifying enzymes in methicillin-resistant Staphylococcus aureus isolates of epidemic phage types
}

\author{
R. VANHOOF, CLAUDINE GODARD, J. CONTENT, H. J. NYSSEN, ELEONORA HANNECART- \\ POKORNI $^{*}$ and the Belgian Study Group of Hospital Infections (GDEPIH/GOSPIZ)
}

Pasteur Institute of Brabant, Engelandstraat 642, 1180 Brussels, Belgium

\begin{abstract}
Summary. The polymerase chain reaction (PCR) was used to identify the aac A-aphD, aphA3 and $a a d C$ genes, encoding the aminoglycoside-modifying enzymes AAC $\left(6^{\prime}\right)-\mathrm{APH}\left(2^{\prime \prime}\right)$, APH( $\left.3^{\prime}\right)$ III and ANT $\left(4^{\prime} 4^{\prime \prime}\right)$, respectively, and the methicillin resistance determinant $m e c A$, in epidemic aminoglycoside and methicillin-resistant isolates of Staphylococcus aureus. In total, 37 isolates collected in the period 1980-1985 and 81 isolates from the period 1991-1992 were obtained from 10 different Belgian hospitals. Epidemic isolates from the earlier period were characterised by phage type $\mathrm{C}(6 / 47 / 54 / 75)$ of phage group III, whereas two other epidemic phage types of group III - types A (77) and B (47/54/75/77/84/85) -were commonest in isolates from the second period. The bifunctional $\mathrm{AAC}\left(6^{\prime}\right)-\mathrm{APH}\left(2^{\prime \prime}\right)$ was the enzyme encountered most frequently. The prevalence of $\mathrm{APH}\left(3^{\prime}\right) \mathrm{III}$ decreased significantly in the 1991-1992 period, while ANT(4', 4") was found solely in isolates from this period. Resistance mechanisms were more complex in isolates from the 1991-1992 period and the mec $A$ gene was detected in all isolates. The PCR results corresponded well with those obtained in the radiochemical phosphocellulose paper binding assay. Isolates from the 1991-1992 period were shown to express significantly higher levels of acetyltransferase activity than isolates from the 1980 s.
\end{abstract}

\section{Introduction}

Staphylococcus aureus is a versatile human pathogen that continues to be an important cause of nosocomial infection. Methicillin-resistant strains of $S$. aureus (MRSA) were recognised soon after the clinical introduction of methicillin. ${ }^{1}$ In 1982, epidemic MRSA strains showing multiple antibiotic resistance and an enhanced capacity to cause widespread outbreaks of infections were described. ${ }^{2}$ Such strains seem to have a special capacity to colonise patients and staff., ${ }^{3,4}$ Although enhanced pathogenicity has often been suggested for epidemic strains of MRSA, there is no firm evidence that these strains are more or less virulent than other strains. ${ }^{5,6}$ The fundamental cause of their pathogenicity remains elusive. Nevertheless, there seems to be a general consensus that infections caused

Received 24 March 1994; accepted 3 May 1994.

* Correspondence should be sent to Dr E. Hannecart-Pokorni. by this type of strain are often associated with a high degree of morbidity and mortality. ${ }^{6,7}$ Furthermore, the presence of additional multiple resistance to a wide range of antibiotics, including aminoglycosides, represents a considerable therapeutic challenge. ${ }^{6,8-11}$

Endemic and epidemic outbreaks of nosocomial infections caused by MRSA have been reported at many centres, and the continuing increase in the incidence of these infections represents an important problem in many countries, including Belgium..$^{9,11-15}$ All these findings justify surveillance programmes in which specific epidemiological markers are used to type the strains and to identify the major source of infection and the main routes of dissemination.

Aminoglycoside resistance mediated by aminoglycoside-modifying enzymes (AMEs) is often plasmid-or transposon-mediated and is, therefore, of considerable clinical importance. The present study describes the identification by polymerase chain reaction (PCR) of genes encoding AMEs in epidemic and laboratory isolates of MRSA in Belgium. 


\section{Materials and methods}

\section{Bacterial isolates}

In total, 118 isolates of $S$. aureus were studied. The isolates were resistant to methicillin and one or more clinically used aminoglycosides. Resistance was determined routinely in the collaborating laboratories by disk diffusion methods. ${ }^{16}$ The isolates were from two different periods.

Period 1980-1985 ("1980 period"). Eight clinical isolates ("IPB isolates") of no known epidemic character were chosen from our laboratory collection for their relatively high level of resistance to aminoglycosides. Also examined were 29 epidemic MRSA isolates from five different hospitals. Eleven of these strains were obtained in 1981 from a hospital in Brussels (HB5); the remaining strains were isolated from septicaemic patients in four other hospitals during a Belgian surveillance study conducted in 1983-1985 by the Institute of Hygiene and Epidemiology, Brussels, Belgium. ${ }^{13}$

Period 1991-1992 ("1991 period"). Eighty-one unrelated epidemic MRSA isolates (obtained from various clinical specimens) were collected in 10 different hospitals as part of a second surveillance study conducted during this period by the Belgian Study Group of Hospital Infections (GDEPIH/GOSPIZ).

The isolates from the two periods were selected to resemble as closely as possible the strain distribution in the hospitals investigated. In total, isolates were obtained from 14 hospitals - one in Aalst (HA), five in Brussels (HB1, HB2, HB3, HB4 and HB5), one in Charleroi-Gilly (HC), one in Geel (HG), one in Ieper (HI), two in Leuven (HL1 and HL2), one in Montignyle-Tilleul (HM), one in Tournai (HT) and one in Yvoir (HY) (tables I and II).

Isolates from the 1980 period were kept lyophilised; isolates from the 1991 period were sent frozen by the GDEPIH and kept at $-80^{\circ} \mathrm{C}$. When required, isolates were rehydrated or thawed and inoculated on to Mueller-Hinton Agar (MHA; Gibco).

S. aureus strains FK422 and FK170 and S. epidermidis strain FK109 were used as reference strains and were kindly supplied by F. H. Kayser (University of Zurich, Switzerland).

\section{Determination of $M I C s$}

MICs of aminoglycosides were determined with a Cooke Dynatech MIC2000 Dispenser and Inoculator and an inoculum size of $1 \mu \mathrm{l}$. The isolates were first grown overnight at $35^{\circ} \mathrm{C}$ on MHA. A few colonies were then suspended in $5 \mathrm{ml}$ of Mueller-Hinton broth (MHB; Gibco) and incubated for $3-5 \mathrm{~h}$ at $35^{\circ} \mathrm{C}$. These cultures were adjusted to match a McFarland No. 1 Standard, then diluted 1 in 20 and inoculated into microdilution plates (Sarstedt) containing $100 \mu \mathrm{l}$ of MHB with doubling antibiotic dilutions to give a final inoculum of $c .1 .5 \times 10^{5} \mathrm{cfu} / \mathrm{ml}$. These plates were then incubated at $35^{\circ} \mathrm{C}$ for $18 \mathrm{~h}$. In every plate, one row without antibiotics served as a control for growth. $S$. aureus strain ATCC25923 was included as a control for the MIC results. The plates were examined on a Cooke Dynatech viewing box and the MIC was recorded as the lowest concentration inhibiting visible growth. Interpretation of resistance was based on the criteria suggested by the French Society for Microbiology. ${ }^{17}$ MICs of the following antibiotics were determined: amikacin, gentamicin, netilmicin and tobramycin.

\section{Enzymic assays for aminoglycoside-modifying enzymes ( $A M E S)$}

Cell-free enzyme extracts were first prepared by growing strains in $200 \mathrm{ml}$ of MHB with aeration $(200 \mathrm{rpm})$ at $37^{\circ} \mathrm{C}$ until the culture was in the logarithmic phase of growth. The bacterial cells were harvested by centrifugation and washed twice in cold Haas No. I buffer. ${ }^{18}$ The cells were lysed by the addition of $150 \mu \mathrm{g}$ of lysostaphin (Sigma) and incubation for $60 \mathrm{~min}$ at $37^{\circ} \mathrm{C}$. In some experiments, cells were also disrupted with an MSE 150-W ultrasonic disintegrator (three 30 -s bursts at $0^{\circ} \mathrm{C}$ and an amplitude of $15 \mu \mathrm{m}$ ). After centrifugation at $100000 \mathrm{~g}$ for $1 \mathrm{~h}$, the supernate was decanted carefully and stabilised with dithiothreitol at a final concentration of $10 \mathrm{~mm}$. Portions $(500 \mu \mathrm{l})$ of these suspensions were stored at $-80^{\circ} \mathrm{C}$.

Aminoglycoside acetylating, nucleotidylating and phosphorylating assays were by the phosphocellulose paper binding assay ${ }^{18}$ with appropriate radiolabelled substrates: $\left[{ }^{14} \mathrm{C}\right]$ acetyl-co-enzyme A $(0.86 \mathrm{~mm}$; specific activity $9.7 \mathrm{Ci} / \mathrm{mol})$; $\left[{ }^{14} \mathrm{C}\right] \mathrm{ATP}(1.2 \mathrm{mM}$; specific activity $8.36 \mathrm{Ci} / \mathrm{mol})$; and $\left[{ }^{32} \mathrm{P}\right] \mathrm{ATP}(0.75 \mathrm{~mm}$; specific activity $13.3 \mathrm{mCi} / \mathrm{mol}$ ) (Amersham International). Assays were allowed to proceed for $30 \mathrm{~min}$ at $35^{\circ} \mathrm{C}$. The amount of radioactivity associated with each aminoglycoside tested was then estimated in a Betaszzint BF5000/300 Liquid Scintillation Counter (Berthold, Wildbad, Germany). Controls without antibiotics and without enzyme preparations were included in each assay run.

In general, two or three aminoglycosides were used to detect the presence of AMEs: amikacin, gentamicin and kanamycin A for acetylating activity; gentamicin and kanamycin $\mathbf{A}$ for phosphorylating activity; and kanamycin A and tobramycin for nucleotidylating activity. For a more precise identification of the enzymes in particular strains, a set of 15 different aminoglycosides was used.

The following aminoglycosides were included in the assays: gentamicin, isepamicin, netilmicin, sisomicin, butirosin, lividomycin, neomycin, ribostamycin, amikacin, kanamycin A and B, apramycin, tobramycin, dibekacin and paromomycin.

\section{Choice of synthetic oligonucleotide primers}

The primer sequences were chosen with a PCR primer selection program $^{19}$ within the nucleotide 
sequences of the published regions of the three genes: $a a c A-a p h D, a p h A 3$ and $a a d C$, encoding the $\mathrm{AAC}\left(6^{\prime}\right)$ $\mathrm{APH}\left(2^{\prime \prime}\right), \mathrm{APH}\left(3^{\prime}\right) \mathrm{III}$ and $\mathrm{ANT}\left(4^{\prime}, 4^{\prime \prime}\right)$ enzymes, respectively. ${ }^{20-22}$ The primers for the mecA gene, encoding methicillin resistance, were chosen according to Murakami et al..$^{23}$ The genes were aligned with an "Align" program to enhance the specificity of the assays by selecting non-identical regions in these genes.

In the sequences of the sense and antisense primers, the numbers in brackets indicate the starting position of the sequence based on the numbering proposed in GenBank under the specific access number for each gene. The sequences chosen were as follows:

$a a c A-a p h D:$ 5'(2022)-CCAAGAGCAATAAGGGCATACC-3' and 5'(2369)-CACACTATCATAACCACTACCG-3' (yielding an amplimer of $222 \mathrm{bp}$ );

aphA3: 5'(329)-CTGATCGAAAAATACCGCTGC-3' and 5'(597)-TCATACTCTTCCGAGCAAAGG-3'(269 bp);

aadC: 5'(605)-CTGCTAAATCGGTAGAAGC-3' and $5^{\prime}(777)$-CAGACCAATCAACATGGCACC$3^{\prime}(174 \mathrm{bp})$;

mecA: 5'(1282)-AAAATCGATGGTAAAGGTTGGC-3' and 5'(1814)-AGTTCTGCAGTACCGGATTTGC-3'(533 bp).

\section{DNA isolation and polymerase chain reaction}

DNA was isolated by a rapid one-step DNA isolation technique. Bacteria were grown overnight at $37^{\circ} \mathrm{C}$ on MHA containing a suitable aminoglycoside. A few (two or three) colonies were suspended in $50 \mu \mathrm{l}$ of PCR mixture- $50 \mathrm{mM} \mathrm{KCl}, 10 \mathrm{mM}$ Tris- $\mathrm{HCl}$, $\mathrm{pH} 9 \cdot 0,2.5 \mathrm{~mm} \mathrm{MgCl}_{2}$, gelatin $0.01 \% \mathrm{v} / \mathrm{v}$, Triton X$100,0 \cdot 1 \% \mathrm{v} / \mathrm{v}, 300 \mu \mathrm{M}$ of each dNTP (Promega) and $0.5 \mu \mathrm{M}$ of each primer. The PCR mixture was then heated to $99^{\circ} \mathrm{C}$ for $10 \mathrm{~min}$ to lyse the bacterial cells. After cooling to $26^{\circ} \mathrm{C}, 1.5 \mathrm{U}$ of $T a q$ Polymerase (Promega) was added to each sample, followed by a drop of mineral oil to prevent evaporation. The samples were then subjected to 32 amplification cycles of $1 \mathrm{~min}$ at $94^{\circ} \mathrm{C}, 2 \mathrm{~min}$ at $60^{\circ} \mathrm{C}$ and $3 \mathrm{~min}$ at $72^{\circ} \mathrm{C}$, followed by a 5 -min extension period at $72^{\circ} \mathrm{C}$. Thermal cycling was performed in a Programmable Heat Block (Hybaid, Teddington). After amplification, 10- $\mu \mathrm{l}$ portions were electrophoresed through a gel of Nusieve 3:1 agarose (FMC, Rockland, ME, USA) $4 \% \mathrm{w} / \mathrm{v}$ in TAE (40 mM Tris-acetate, $1 \mathrm{~mm}$ EDTA, $\mathrm{pH} \mathrm{8.0)}$ and the PCR products were visualised by staining with ethidium bromide $0.05 \% \mathrm{w} / \mathrm{v}$. In each run, a negative control to detect any contamination of the reagents and $\mathrm{HaeIII}$-digested $\phi \mathrm{X} 174 \mathrm{RF}$ DNA size markers (BRL-Gibco) were included. All isolates were tested at least twice before they were considered as positive.

\section{Phage-typing}

Bacteriophage typing was with the International Typing Set at the routine test dilution (RTD) and
RTD $\times 100$. Phages used included lytic-group I (phages 29, 52, 52A, 79 and 80), group II (phages 3A, $3 \mathrm{C}, 55$ and 71 ), group III (phages 6, 42E, 47, 53, 54, 75, $77,83 \mathrm{~A}, 84$ and 85 ), group $\mathrm{V}$ (phages 94 and 96) and a non-allocated (miscellaneous) group (phages 81 and 95). S. aureus isolates were considered to have different phage types if there was either a difference in phage lytic group or if there was a difference in two or more lytic reactions for isolates belonging to the same group. The strain was considered as non-typable if there was no lysis at RTD or RTD $\times 100$ for each of the phages tested.

An epidemic situation in a hospital was surmised when at least three isolates with the same phage type were found among 10 successive MRSA isolates.

\section{Statistical evaluation}

Statistical evaluation was with the $\chi^{2}$ test, the MannWhitney U test, Student's $t$ test and Spearman's rank correlation coefficient $r_{s}$ when indicated. The level of significance was set at $\mathrm{p} \leqslant 0.05$.

\section{Results}

\section{Susceptibility data}

The distribution of MICS of the different aminoglycosides for MRSA isolates from the two periods are shown in fig. 1. There was a significant shift to higher MICs of netilmicin $(0.02>p>0.01)$, amikacin and tobramycin (both $p<0.001$ ) for MRSA isolates in the 1991 period. There was a non-significant tendency $(0.2>p>0.1)$ towards higher MICs of gentamicin.

In both periods, netilmicin had the lowest MIC values and was significantly more active against MRSA isolates than the other aminoglycosides $(0.02>p>0.01$ compared to amikacin in the 1991 period; $p<0.001$ for all other comparisons). Netilmicin also showed the lowest prevalence of resistance $-0 \%$ in the 1980 period and $1.2 \%$ in the 1991 period. Isolates with intermediate resistance to netilmicin comprised $10.3 \%$ in the 1980 period and $9.9 \%$ in the 1991 period. Resistance to amikacin was found in $6.9 \%$ of the isolates from the 1980 period and $6.2 \%$ from the 1991 period, with a significant increase in strains with intermediate resistance to amikacin (from $0 \%$ to $24.7 \% ; 0.01>p>0.001$ ). For gentamicin, the level of resistance remained practically identical in the two periods- $-89.7 \%$ and $86.4 \%$. For tobramycin, there was a significant increase in resistant strains in the 1991 period (from $62.1 \%$ to $95.1 \% ; \mathrm{p}<0.001$ ), accompanied by a significant decrease in strains with intermediate resistance (from $27.6 \%$ to $1.2 \%$; $\mathrm{p}<0.001)$.

\section{Aminoglycoside-modifying enzymes (AMEs)}

The results of assays for AMEs are presented in tables I and II. Acetyltransferase activity varied 


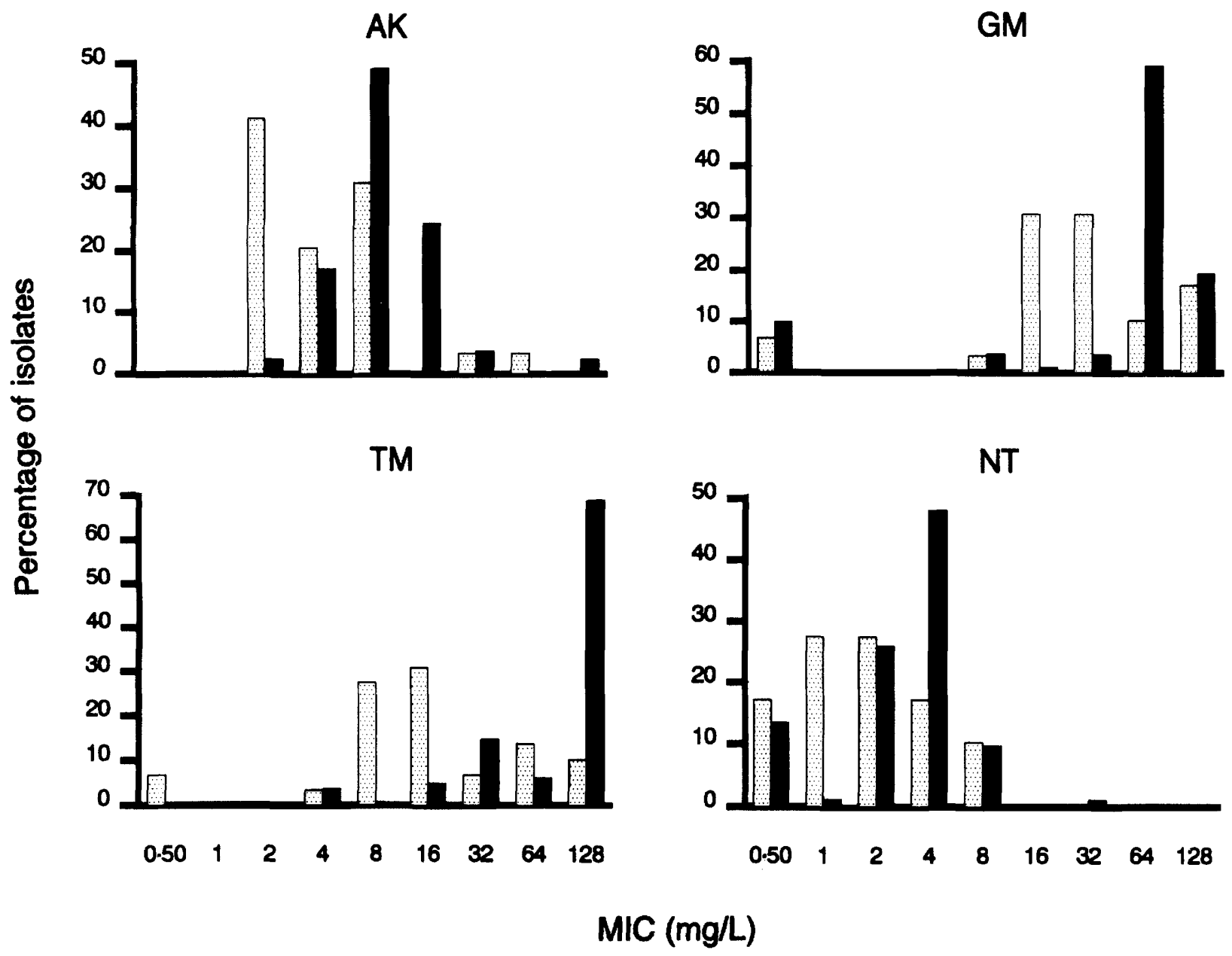

Fig. 1. Distribution of in-vitro MICs of aminoglycosides for epidemic methicillin-resistant S. aureus isolates from the "1980 period" (圆) and

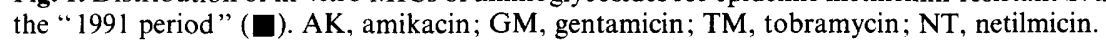

Table I. Aminoglycoside-modifying enzymes and phage types in aminoglycoside-resistant mec $A$-positive $S$. aureus isolates from Belgian hospitals (1980-1985)

\begin{tabular}{|c|c|c|c|c|c|c|}
\hline \multirow{2}{*}{ Hospital* } & \multirow{2}{*}{$\begin{array}{l}\text { Total } \\
\text { number of } \\
\text { strains }\end{array}$} & \multirow{2}{*}{$\begin{array}{c}\text { Aminoglycoside resistance } \\
\text { profile } \\
\text { (number of strains) }\end{array}$} & \multicolumn{3}{|c|}{ Number of strains expressing each enzyme $\dagger$} & \multirow{2}{*}{$\begin{array}{c}\text { Phage type } \neq \\
\text { (number of strains) }\end{array}$} \\
\hline & & & $\mathrm{AAC}\left(6^{\prime}\right)-\mathrm{APH}\left(2^{\prime \prime}\right)$ & $\operatorname{ANT}\left(4^{\prime}, 4^{\prime \prime}\right)$ & $\mathrm{APH}\left(3^{\prime}\right) \mathrm{Ill}$ & \\
\hline \multirow[t]{3}{*}{$\mathrm{HA}$} & 8 & ak Gm nt TM (5) & 5 & 0 & 5 & $C(5)$ \\
\hline & & ak $\mathrm{Gm} \operatorname{tm}(1)$ & 1 & 0 & 0 & $C(1)$ \\
\hline & & Other (2) & 0 & 0 & 2 & $C(2)$ \\
\hline \multirow[t]{2}{*}{ HB4 } & 8 & $\operatorname{Gm} \operatorname{Tm}(7)$ & 7 & 0 & 7 & $\mathrm{C}(4) ; \mathrm{C}^{+}(2) ; \mathrm{C}^{\circ 0}(1)$ \\
\hline & & Ak Gm Nt Tm (1) & 1 & 0 & 1 & $C(1)$ \\
\hline \multirow[t]{3}{*}{ HB5 } & 11 & $\operatorname{Gm} \operatorname{Tm}(8)$ & 8 & 0 & 8 & $\mathrm{C}(4): \mathrm{C}^{+}(2): \mathrm{C}^{+\infty}(1): \mathrm{E}(1)$ \\
\hline & & ak Gm Tm (2) & 2 & 0 & 2 & $\mathrm{C}^{+}(1): \mathrm{E}(1)$ \\
\hline & & Ak Gm Nt Tm (1) & 1 & 0 & 1 & $\mathrm{C}^{+}(1)$ \\
\hline HL2 & 1 & $\operatorname{Gm} \operatorname{Tm}(1)$ & 1 & 0 & 1 & A (1) \\
\hline HM & 1 & $\mathrm{Gm} \operatorname{Tm}(1)$ & 1 & 0 & 1 & $A(1)$ \\
\hline \multirow[t]{2}{*}{ IPB } & 8 & ak $\operatorname{Gm} \operatorname{Tm}(4)$ & 4 & 0 & 4 & $C(2): D(2)$ \\
\hline & & Ak Gm Tm (4) & 4 & 0 & 0 & $C(2) ; D(1) ; E(1)$ \\
\hline
\end{tabular}

$\mathrm{Ak}$, amikacin; Gm, gentamicin; Nt, netilmicin; Tm, tobramycin; ak, gm, nt and tm indicate intermediate resistance.

*See text.

$\dagger$ Determined by the phosphocellulose paper binding assay and PCR.

$\ddagger$ Determined at the routine test dilution (RTD) for phage types A, C, D and E, and at RTD $\times 100$ for phage type $\mathrm{C}^{\circ \circ}$.

markedly amongst the isolates from the two periods. Fig. 2 compares the enzymic modification profile of an isolate (Sta. 810416s) from the 1980 period - with low acetylating activity - with the profile of an isolate (Sta. 920098s) from the 1991 period with high acetylating activity. Fig. 3 compares the acetylating activity, with amikacin as the substrate, of isolates expressing the bifunctional $\mathrm{AAC}\left(6^{\prime}\right)-\mathrm{APH}\left(2^{\prime \prime}\right)$ enzyme. A significantly higher level of acetyltransferase activity was found in isolates from the 1991 period compared with isolates from the 1980 period ( $p<0.001)$. A significant increase in phosphorylating activity was not found $(0.7>p>0.5)$. There was no correlation between acetylating activity and the MIC of amikacin ( $p>0.9$ 
Table II. Aminoglycoside-modifying enzymes and phage types in aminoglycoside-resistant mec $A$-positive $S$. aureus isolates from Belgian hospitals (1991-1992)

\begin{tabular}{|c|c|c|c|c|c|c|}
\hline \multirow{2}{*}{ Hospital* } & \multirow{2}{*}{$\begin{array}{l}\text { Total } \\
\text { number of } \\
\text { strains }\end{array}$} & \multirow{2}{*}{$\begin{array}{c}\text { Aminoglycoside resistance } \\
\text { profile } \dagger \\
\text { (number of strains) }\end{array}$} & \multicolumn{3}{|c|}{ Number of strains expressing each enzyme $\ddagger$} & \multirow{2}{*}{$\begin{array}{c}\text { Phage type§ } \\
\text { (number of strains) }\end{array}$} \\
\hline & & & $\mathrm{AAC}\left(6^{\prime}\right)-\mathrm{APH}\left(2^{\prime \prime}\right)$ & $\operatorname{ANT}\left(4^{\prime}, 4^{\prime \prime}\right)$ & $\mathrm{APH}\left(3^{\prime}\right) \mathrm{III}$ & \\
\hline $\mathrm{HG}$ & 8 & ak $\operatorname{Tm}(8)$ & 0 & 8 & 0 & $\mathrm{C}^{\circ 0}(8)$ \\
\hline $\mathrm{HB} 1$ & 7 & Ak Gm Nt Tm (7) & 7 & 7 & 0 & A (7) \\
\hline \multirow{2}{*}{ HB2 } & 9 & Ak Gm nt $\operatorname{Tm}(4)$ & 4 & 4 & 0 & B (3); G (1) \\
\hline & & $\operatorname{Gm} \operatorname{Tm}(5)$ & 5 & 0 & 0 & $\mathrm{~A}(3) ; \mathrm{C}(1) ; \mathrm{H}(1)$ \\
\hline \multirow[t]{4}{*}{ HB3 } & 9 & ak Gm nt Tm (4) & 4 & 4 & 0 & A (4) \\
\hline & & $\mathrm{Gm} n t \operatorname{Tm}(3)$ & 3 & 0 & 0 & A (3) \\
\hline & & Ak Gm nt Tm (1) & 1 & 0 & 0 & $E(1)$ \\
\hline & & $\mathrm{Gm} \mathrm{Nt} \operatorname{tm}(1)$ & 1 & 1 & 0 & $D^{\circ}(1)$ \\
\hline \multirow[t]{4}{*}{ HB4 } & 10 & ak Gm nt Tm (5) & 5 & 5 & 5 & $\mathrm{~A}(2) ; \mathrm{B}(2) ; \mathrm{D}(1)$ \\
\hline & & $\mathrm{Gm} \operatorname{tm}(1)$ & 1 & 1 & I & B (1) \\
\hline & & ak Gm nt Tm (3) & 3 & 0 & 0 & B (2): $C^{\circ 0}(1)$ \\
\hline & & Ak Gm nt Tm (1) & 1 & 0 & 1 & $D(1)$ \\
\hline $\mathrm{HC}$ & 9 & ak Gm nt Tm (9) & 9 & 9 & 6 & $\mathrm{~A}(7) ; \mathbf{B}(2)$ \\
\hline $\mathrm{HI}$ & 8 & Ak Gm nt Tm (8) & 8 & 8 & 3 & $\mathrm{~A}^{\circ \circ}(4) ; \mathrm{NT}(3) ; \mathrm{B}(1)$ \\
\hline HLI & 4 & ak Gm nt Tm (4) & 4 & 0 & 0 & $\mathbf{B}(2) ; \mathbf{B}^{-}(1) ; \mathrm{E}^{+}(1)$ \\
\hline \multirow[t]{2}{*}{ HY } & 10 & ak Gm nt Tm (7) & 7 & 7 & 0 & A (5); B (1); F (1) \\
\hline & & $\mathrm{Gm} \mathrm{nt} \mathrm{Tm} \mathrm{(3)}$ & 3 & 0 & 0 & A (2); B (1) \\
\hline $\mathrm{HT}$ & 7 & ak Gm nt Tm (7) & 7 & 7 & 0 & B (7) \\
\hline
\end{tabular}

*See text.

+See table I.

†Determined by the phosphocellulose paper binding assay and PCR

$\S$ Determined at the routine test dilution (RTD) for phage types A-H, and at RTD $\times 100$ for phage types $\mathrm{A}^{\circ \circ}-\mathrm{D}^{\circ \circ}$; NT, not typable

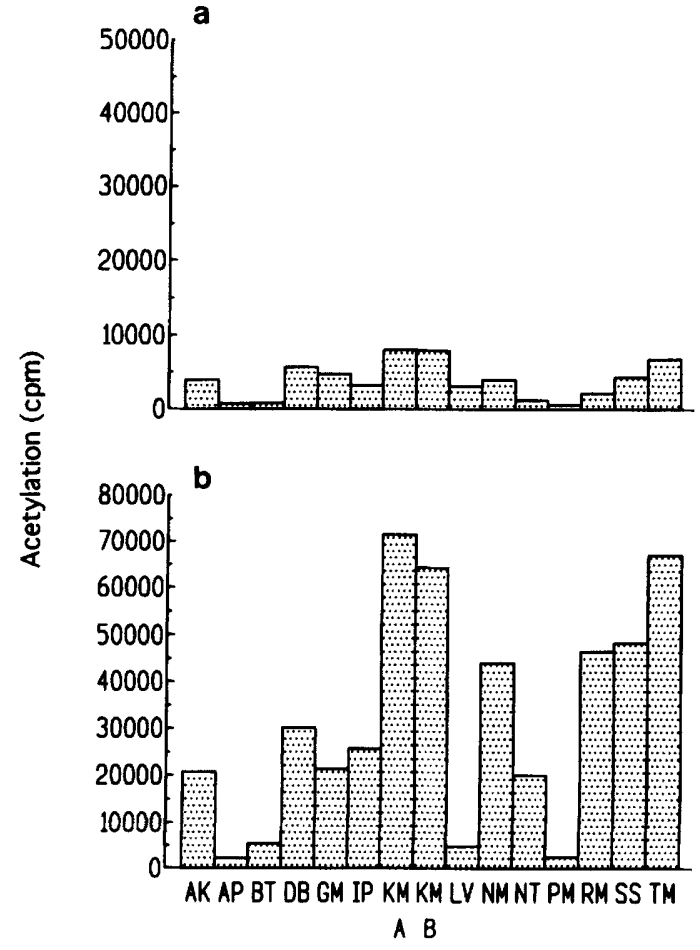

Aminoglycoside substrate

Fig. 2. Enzymic modification profiles of two staphylococcal isolates-(a) $810416 \mathrm{~s}$ and (b) $920098 \mathrm{~s}$ - synthesising the bifunctional AAC (6')-APH (2") enzyme. AK, amikacin; AP, apramycin; BT, butirosin; DB, dibekacin; GM, gentamicin; KM A and B, kanamycin A and B; LV, lividomycin; NM, neomycin; NT, netilmicin; PM, paromomycin; RM, ribostamycin; SS, sisomicin; TM, tobramycin.

for the 1980 period and $0.3>p>0.2$ for the 1991 period).

\section{PCR experiments}

Specificity. The specificity of the different sets of primers was tested with DNA extracts of the reference

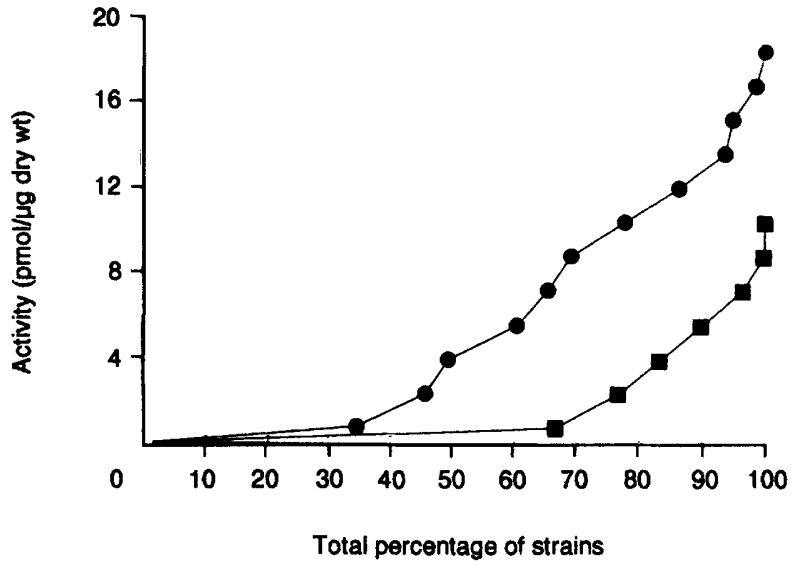

Fig. 3. Comparison of the $\mathrm{N}$-acetyltransferase activities-expressed as pmol $/ \mu \mathrm{g}$ dry weight with amikacin as the substrate--of isolates expressing the AAC $\left(6^{\prime}\right)-\mathrm{APH}\left(2^{\prime \prime}\right)$ enzyme from the 1980 period ( and the 1991 period $(\mathbf{O})$.

strains FK422, FK170 and FK109 containing, respectively, the aacA-aphD, aphA3 and aadC genes. Primers for the $m e c A$ gene were tested with DNA from strain Sta.810442s from our laboratory stock. The reference strains generated a band of amplified DNA with the corresponding specific sets of primers (fig. 4 , lanes 1-4).

Detection of AMEs in clinical isolates. The PCR technique was applied to the clinical isolates to detect the presence of genes encoding AMEs. The results of these experiments are shown in tables I and II. Fig. 4 illustrates the results of PCR experiments with two clinical isolates. Isolate Sta.810442s from the 1980 period contains the aacA-aphD and the aphA3 genes (fig. 4, lane 5), whereas isolate Sta.920399s contains the $a a c A-a p h D$ and the $a a d C$ genes (fig. 4, lane 6). Isolates reported as methicillin-resistant by the participating laboratories each generated a specific DNA band following amplification with the mecA primers, and the detection of AME-encoding genes by PCR 


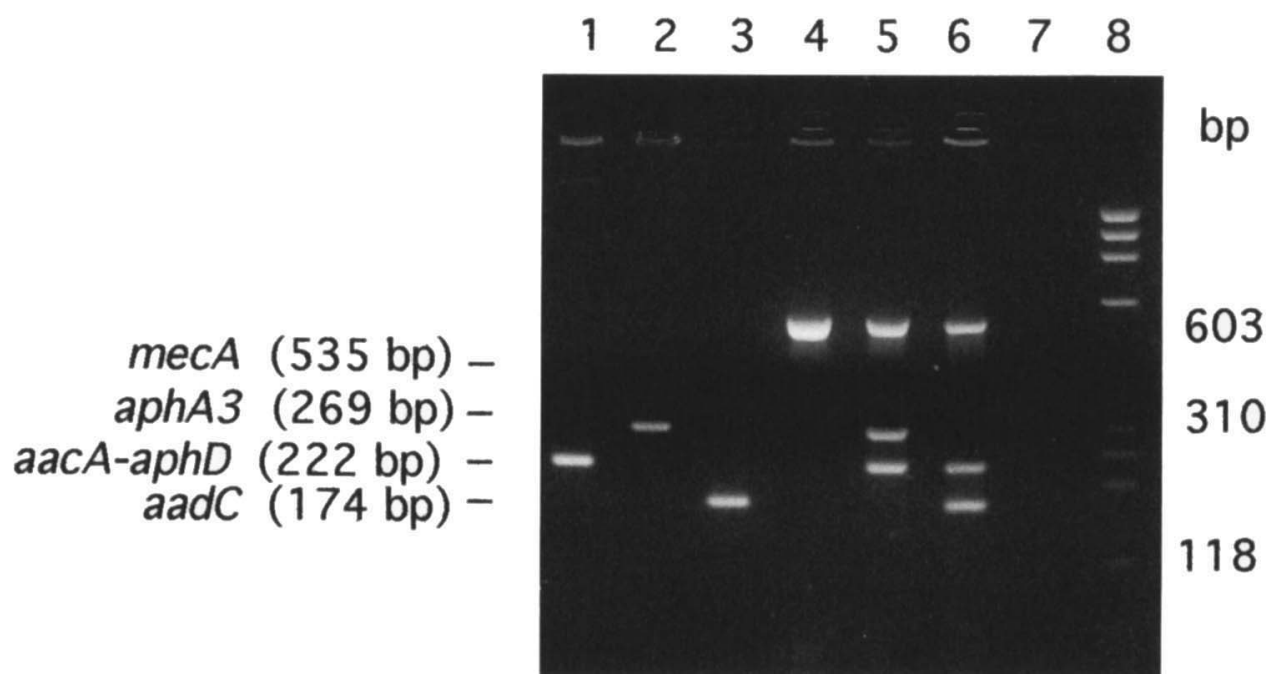

Fig. 4. Ethidium bromide-stained agarose gel of amplified DNA fragments from reference strains and clinical MRSA isolates. Lane 1, $S$. aureus FK422 (aacA-aphD); 2, S. aureus FK170 (aphA3); 3, S. epidermidis FK109 (aadC); 4, MRSA Sta.810442s (mecA); 5, MRSA Sta.810422s (mecA, aacA-aphD, aphA3); 6, MRSA Sta.920399s (mecA, aacA-aphD, aadC); 7, negative control; 8, HaeIII-digested $\phi X 174$ size markers. AMEs indicated in parenthesis were those whose presence was indicated following amplification with the corresponding primer sets. Isolates in lanes $\mathbf{5}$ and $\mathbf{6}$ were amplified with the four sets of primers simultaneously.

Table III. The distribution of phage patterns corresponding to MRSA phage types A-H in the 1980 and 1991 periods

\begin{tabular}{llcc}
\hline & & \multicolumn{2}{c}{ Number of strains } \\
\cline { 3 - 4 } $\begin{array}{l}\text { Phage } \\
\text { type }\end{array}$ & Sensitivity to phages & $\begin{array}{c}1980 \\
\text { period }\end{array}$ & $\begin{array}{c}1991 \\
\text { period }\end{array}$ \\
\hline A & 77 & 2 & 37 \\
B & $47 / 54 / 75 / 77 / 84 / 85$ & 0 & 22 \\
B $^{-}$ & $47 / 54 / 75 / 85$ & 0 & 1 \\
C & $6 / 47 / 54 / 75$ & 22 & 10 \\
C $^{+}$ & $6 / 47 / 54 / 75 / 77 / 84$ or 85 & 7 & 0 \\
D & 85 & 3 & 3 \\
E & $77 / 84 / 85$ & 3 & 1 \\
E $^{+}$ & $77 / 84 / 85 / 95$ & 0 & 1 \\
F & $77 / 83 \mathrm{~A} / 85$ & 0 & 1 \\
G & $47 / 75 / 77$ & 0 & 1 \\
H & $79 / 6 / 42 E / 47 / 85 / 81 / 95$ & 0 & 1 \\
NT & Non-typable & 0 & 3 \\
& & & \\
\hline
\end{tabular}

was in agreement with results obtained by the phosphocellulose paper binding assay.

The aac $A-a p h D$ gene was encountered most frequently in the 1991 period, but the aphA3 gene was more prevalent in the 1980 period. The aadC gene was found only in isolates from the 1991 period, whereas the aphA3 gene was significantly more prevalent in the 1980 period compared with the 1991 period ( $\mathrm{p}<0.001)$. In both periods, the aacA-aphD gene was found mostly in combination with other genes. Of the isolates of the 1980 period, $90 \%$ harboured this bifunctional gene in combination with the aphA3 gene, whereas this combination was found only in $1.2 \%$ of the 1991 isolates $(p<0.001)$. The most frequent combination of genes amongst isolates from the 1991 period was the $a a c A-a p h D+a a d C$ combination $(47 \%$ of isolates). The triple combination of aacA$a p h D+a a d C+a p h A 3$ was not found in isolates from the 1980 period, but was present in $19 \%$ of isolates from the 1991 period $(0.05>p>0.02)$ and was found in isolates from three hospitals (HB4, HC and HI). In isolates from $\mathrm{HG}$, only the $a a d C$ gene was detected. The presence of genes, or combinations of genes, encoding AMEs for which amikacin is a substrate was indicated in isolates considered as susceptible (29\%) or of intermediate resistance $(50 \%)$ in MIC tests; however, all isolates harbouring the aacA-aphD gene were clearly resistant to gentamicin in MIC tests.

\section{Phage-typing}

Phage types encountered amongst the MRSA isolates are listed in table III. The majority of the phage types belonged to phage group III, although two isolates with phage types $\mathrm{E}^{+}$and $\mathrm{H}$ also showed significant reactions with phages belonging to other groups. Phage types $\mathrm{C}$ and $\mathrm{C}^{+}$predominated in the 1980 period, whereas most strains of the 1991 period belonged to types A and B. Less than $2.5 \%$ ( 3 of 118) of the isolates were non-typable.

The phage-type distribution amongst the isolates of the different hospitals is shown in tables I and II. There was no particular correlation between the phage types and the presence of genes for AMEs. In the 1980 period, only two isolates belonged to phage type A-which spread epidemically in the 1991 periodwhile phage type $C$ was epidemic in three hospitals (HA, HB4 and HB5). All eight isolates from $\mathrm{HG}$, harbouring the ANT $\left(4^{\prime}, 4^{\prime \prime}\right)$ enzyme, belonged to the rather peculiar phage type $\mathrm{C}^{\circ 0}$.

\section{Discussion}

MRSA play an important role in nosocomial infection. Epidemiological monitoring of MRSA is an essential step in the development of control programmes and a wide variety of epidemiological 
markers is used, such as biotype, phage type, plasmid profile and antibiotype. The present paper reports the distribution and evolution of phage types and genetic determinants of AMEs in epidemic MRSA isolates from various Belgian hospitals. Furthermore, the utility of the PCR technique to detect and identify genes encoding AMEs was validated.

Phage typing of $S$. aureus has been standardised internationally and is regarded generally as a useful epidemiological tool, although its discriminating capacity has been questioned in some cases. ${ }^{9,24,25}$ In the present study, most isolates from the 1980 period belonged to phage group III, and particularly to phage type $6 / 47 / 54 / 75$. Phage types A and B of phage group III, with sensitivity to phages 77 and $47 / 54 / 75 / 77 / 84 / 85$, respectively, were most prevalent among isolates from the 1991 period. It should be noted that phage types A and B represent subclones that are closely related genetically. No particular linkage between phage types and AME genes was found, although the fact that all isolates that harboured only the aadC gene belonged to phage type $\mathrm{C}^{\circ 0}$ may be worthy of further investigation.

Increased antibiotic resistance in MRSA has been reported worldwide and may compromise the therapeutic effectiveness of antimicrobial agents. ${ }^{6,8-11,25,26}$ The simultaneous presence of genetic determinants coding for resistance to different antibiotics leads to an important narrowing of the therapeutic index. Aminoglycosides have been used in the treatment of staphylococcal infections, but the development of resistance, mostly caused by AMEs, will seriously limit their effectiveness. The bifunctional AAC $\left(6^{\prime}\right)-\mathrm{APH}\left(2^{\prime \prime}\right)$ enzyme, which is restricted to gram-positive bacteria, inactivates a broad range of clinically useful aminoglycosides because it catalyses both acetyltransferase and phosphotransferase reactions. Various techniques, such as MIC ratios, the radiochemical phosphocellulose paper binding assay, and some molecular diagnostic methods, are used to identify AMEs or their corresponding genes.

The PCR technique has been shown previously to be a reliable tool for the identification of AME genes in gram-negative bacteria ${ }^{27,28}$ and was used in the present study to detect and identify genes encoding AMEs in epidemic MRSA isolates. For this purpose, three sets of primers delineating specific DNA fragments of the aac $A-a p h D, a p h A 3$ and $a a d C$ genes were defined. These sets of primers were assessed with reference strains encoding various AMEs. Amplification fragments specific for the AME genes were detected clearly from staphylococcal reference strains. No specific DNA fragments were detected when these primers were used on reference strains harbouring genes other than those mentioned above (data not shown). Furthermore, complete agreement was found between the results of the radiochemical phosphocellulose paper binding assay ${ }^{18}$ and the PCR technique.

The radiochemical technique is considered to be a reliable method for the detection of AMEs, but is a costly and time-consuming technique which uses radiolabelled products. Furthermore, it may fail to detect low levels of intracellular enzymes, especially $\operatorname{ANT}\left(2^{\prime \prime}\right),{ }^{29}$ and results are not always easy to interpret when enzyme combinations of the same subclass are present. In the present study, isolates, especially from the 1980 period, with very low enzymic activity were found. Such borderline activity may be neglected or misinterpreted, and the more clear-cut results obtained with the PCR technique were much easier to interpret. However, the radiochemical technique does allow expression of enzymic activity to be followed. Significantly higher acetyltransferase activity was found in isolates from the 1991 period that produced $\mathrm{AAC}\left(6^{\prime}\right)$ APH(2") compared with those from the 1980 period. The increased enzymic activity was paralleled by a significant shift towards higher MICs of amikacin and tobramycin, although there was no direct correlation between enzymic activity and MIC values. Moreover, combinations of AMEs were detected in MRSA isolates which would be regarded as amikacin-susceptible by internationally accepted sensitivity standards, indicating that MICs are not always indicative of the presence of particular AMEs. Interestingly all isolates expressing only the bifunctional AAC $\left(6^{\prime}\right)-\mathrm{APH}\left(2^{\prime \prime}\right)$ enzyme were neomycinsusceptible (data not shown).

$\mathrm{AAC}\left(6^{\prime}\right)-\mathrm{APH}\left(2^{\prime \prime}\right)$ was the enzyme encountered most frequently among the isolates, as has been reported in other centres. ${ }^{30-36}$ The APH( $\left.3^{\prime}\right)$ III enzyme decreased significantly in importance between the 1980 and 1991 periods. The ANT $\left(4^{\prime}, 4^{\prime \prime}\right)$ enzyme, which was not detected in the isolates of the 1980 period, was present in $75 \%$ of the 1991 isolates. The occurrence of this enzyme resulted in more complex resistance mechanisms, since $18.5 \%$ of the 1991 isolates possessed genes for the three distinct AMEs. The ANT $\left(4,4^{\prime \prime}\right)$ enzyme appears to have been relatively rare in European isolates at the beginning of the $1980 \mathrm{~s}^{30,32,35}$ Madsen et al $^{35}$ observed no change in the distribution of AMEs in Danish staphylococcal isolates during 1979-1987, while an increasing prevalence of the ANT $\left(4,4^{\prime \prime}\right)$ enzyme was noted in a European collaborative study. ${ }^{31,32}$ The European Study Group on Antibiotic Resistance (ESGAR) ${ }^{32}$ detected the ANT $\left(4^{\prime}, 4^{\prime \prime}\right)$ enzyme in $11.2 \%$ of staphylococci isolated consecutively from blood and urine during $1984-1985$, increasing to $46.1 \%$ in the $1987-$ 1988 survey. ${ }^{31}$ An important variation in the prevalence of AMEs in isolates from Central and Northern Europe compared with Southern Europe was reported in both studies. Interestingly, important differences in the distribution of bacterial resistance determinants have also been reported in more restricted geographic areas. $^{33,37}$ These changes in prevalence of AMEs can be caused by changes in antibiotic policies or can be explained by the introduction and consequent interhospital spread of resistant strains. Finally, it cannot be excluded that these resistance genes originated from an environmental source. Indeed, saprophytic staphy- 
lococci have frequently been reported to carry resistance determinants, including those for AMEs, ${ }^{30-34}$ and can, therefore, function as a reservoir for the genetic determinants of these enzymes. Conjugational transfer of resistance determinants between $S$. aureus and $S$. epidermidis, leading to rapid dissemination of these determinants in the hospital environment, has been demonstrated..$^{38,39}$

\section{References}

1. Jevons MP. "Celbenin"-resistant staphylococci. BMJ 1961; 1: $124-125$.

2. Pavillard R, Harvey K, Douglas D et al. Epidemic of hospitalacquired infection due to methicillin-resistant Staphylococcus aureus in major Victorian hospitals. Med $J$ Aust $1982 ; 1: 451-454$

3. Casewell MW, Hill RLR. The carrier state: methicillin-resistant Staphylococcus aureus. J Antimicrob Chemother 1986; 18 Suppl A: 1-12.

4. Cookson B, Peters B, Webster M, Phillips I, Rahman M, Noble W. Staff carriage of epidemic methicillin-resistant Staphylococcus aureus. J Clin Microbiol 1989; 27: 1471-1476.

5. Coleman DC, Cafferkey M, Keane CT et al. Mechanisms of pathogenicity of multi-resistant Staphylococcus aureus. $J$ Hosp Infect 1986; 7 Suppl A: 29-35.

6. Cookson BD, Phillips I. Methicillin-resistant staphylococci. Soc Appl Bacteriol Symp Ser 1990; 19: 55S-70S.

7. Locksley RM, Cohen ML, Quinn TC et al. Multiply antibioticresistant Staphylococcus aureus: introduction, transmission, and evolution of nosocomial infection. Ann Intern Med 1982; 97: 317-324.

8. Brumfitt W, Hamilton-Miller J. Methicillin-resistant Staphylococcus aureus. $N$ Engl J Med 1989; 320: 1188-1196.

9. Cookson BD, Phillips I. Epidemic methicillin-resistant Staphylococcus aureus. $J$ Antimicrob Chemother 1988; 21 Suppl C: $57-65$.

10. Maple PAC, Hamilton-Miller JMT, Brumfitt W. World-wide antibiotic resistance in methicillin-resistant Staphylococcus aureus. Lancet $1989 ; 1$ : 537-540.

11. Schito GC, Varaldo PE. Trends in the epidemiology and antibiotic resistance of clinical Staphylococcus strains in Italy - a review. J Antimicrob Chemother 1988; 21 Suppl C: 67-81.

12. Casewell MW. Epidemiology and control of the "modern" methicillin-resistant Staphylococcus aureus. $J$ Hosp Infect 1986; 7 Suppl A: 1-11.

13. Institut d'Hygiène et d'Epidémiologie, Ministère de la Santé Publique et de l'Environnement. Etude des souches hospitalières de Staphylococcus aureus isolées en Belgique. Brussels, Ministère de la Santé Publique et de l'Environnement. 1987: 1-16.

14. Jorgensen JH. Laboratory and epidemiologic experience with methicillin-resistant Staphylococcus aureus in the USA. Eur J Clin Microbiol 1986; 5: 693-696.

15. Vickery AM. Strains of methicillin-resistant Staphylococcus aureus isolated in Australian hospitals from 1986 to 1990. Australian Group for Antimicrobial resistance. $J$ Hosp Infect 1993; 24: 139-151.

16. National Committee for Clinical Laboratory Standards. Performance standard for antimicrobial disk susceptibility tests. Villanova, PA, NCCLS. 1992.

17. Acar J, Bergogne-Bérézin E, Brognard JM et al. Communiqué 1993 du comité de l'antibiogramme de la Société Française de Microbiologie. Path Biol 1993; 41: 741-748.

18. Haas MJ, Dowding JE. Aminoglycoside-modifying enzymes. Methods Enzymol 1975; 43: 611-628

19. Lowe T, Sharefkin J, Yang SQ, Dieffenbach CW. A computer program for selection of oligonucleotide primers for polymerase chain reactions. Nucleic Acids Res 1990: 18: $1757-1761$.

20. Gray GS, Fitch WM. Evolution of antibiotic resistance genes: the DNA sequence of a kanamycin resistance gene from Staphylococcus aureus. Mol Biol Evol 1983; 1 : 57-66.
In conclusion, the PCR technique was shown to be a reliable technique for studying the presence and evolution of antibiotic resistance markers in epidemic MRSA. The technique has the potential to be of great help for early detection of resistance genes in an epidemiological setting.

We acknowledge the editorial assistance of $\mathbf{J}$. M. Pirotte and F. Depuydt.

21. Matsumura M, Katakura Y, Imanaka T, Aiba S. Enzymatic and nucleotide sequence studies of a kanamycininactivating enzyme encoded by a plasmid from thermophilic bacilli in comparison with that encoded by plasmid pUB110. J Bacteriol 1984; 160: 413-420.

22. Rouch DA, Byrne ME, Kong YC, Skurray RA. The $a a c A-a p h D$ gentamicin and kanamycin resistance determinant of Tn4001 from Staphylococcus aureus: expression and nucleotide sequence analysis. $J$ Gen Microbiol 1987; 133: 3039-3052.

23. Murakami K, Minamide W, Wada K, Nakamura E, Teraoka $\mathrm{H}$, Watanabe $\mathrm{S}$. Identification of methicillin-resistant strains of staphylococci by polymerase chain reaction. J Clin Microbiol 1991; 29: 2240-2244.

24. Cookson B, Talsiana H, Naidoo J, Phillips I. Strategies for typing and properties of epidemic methicillin-resistant Staphylococcus aureus. Eur J Clin Microbiol 1986; 5: 702-709.

25. Mulligan ME, Arbeit RD. Epidemiologic and clinical utility of typing systems for differentiating among strains of methicillin-resistant Staphylococcus aureus. Infect Control Hosp Epidemiol 1991; 12: 20-28.

26. Van der Auwera P, Godard C, Denis C, De Maeyer S, Vanhoof $R$. In vitro activities of new antimicrobial agents against multiresistant Staphylococcus aureus isolated from septicemic patients during a Belgian national survey from 1983 to 1985. Antimicrob Agents Chemother 1990; 34: 2260-2262.

27. Vanhoof R, Content J, Van Bossuyt E, Dewit L, HannecartPokorni E. Identification of the $a a d B$ gene coding for the aminoglycoside-2"-O-nucleotidyltransferase, ANT(2"), by means of the polymerase chain reaction. $J$ Antimicrob Chemother 1992; 29: 365-374

28. Vanhoof $\mathrm{R}$, Content $\mathrm{J}$, Van Bossuyt $\mathrm{E}$ et al. Use of the polymerase chain reaction (PCR) for the detection of a $\mathrm{ac} A$ genes encoding aminoglycoside- $6^{\prime}-\mathrm{N}$-acetyltransferases in reference strains and gram-negative clinical isolates from two Belgian hospitals. J Antimicrob Chemother 1993; 32: 23-35.

29. Tenover FC, Gootz TD, Gordon KP, Tompkins LS, Young SA, Plorde JJ. Development of a DNA probe for the structural gene of the 2"-O-adenyltransferase aminoglycoside-modifying enzyme. J Infect Dis 1984; 150 : 678-687.

30. Bengtsson S, Bernander S, Brorson JE et al. In vitro aminoglycoside resistance of gram-negative bacilli and staphylococci isolated from blood in Sweden 1980-1984. Scand J Infect Dis 1986; 18: 257-263.

31. Dornbusch K, Miller GH, Hare RS, Shaw KJ. Resistance to aminoglycoside antibiotics in gram-negative bacilli and staphylococci isolated from blood. Report from a European collaborative study. The ESGAR study group (European Study Group on Antibiotic Resistance). $J$ Antimicrob Chemother 1990; 26: 131-144.

32. European Study Group on Antibiotic Resistance. In vitro susceptibility to aminoglycoside antibiotics in blood and urine isolates consecutively collected in twenty-nine European laboratories. Eur J Clin Microbiol 1987: 6: 378-385.

33. Huovinen P, Grönroos P, Herva E et al. Aminoglycoside resistance among blood culture isolates. $J$ Clin Microbiol $1984 ; 20: 65-69$.

34. Lovering AM, Bywater MJ, Holt HA, Champion HM, Reeves DS. Resistance of bacterial pathogens to four amino- 
glycosides and six other antibacterials and prevalence of aminoglycoside modifying enzymes, in 20 UK centres. $J$ Antimicrob Chemother 1988; 22: 823-839.

35. Madsen OR, Lorentzen JS, Frimodt-Møller N, Mortensen I, Rosdahl VT. Mechanisms of aminoglycoside resistance in Danish Staphylococcus aureus strains during the years 1979-1987. APMIS 1991; 99: 537-540.

36. Price KE, Kresel PA, Farchione LA, Siskin SB, Karpow SA Epidemiological studies of aminoglycoside resistance in the U.S.A. J Antimicrob Chemother 1981; 8 Suppl A: 89-105.

37. Vanhoof R, Godard C, Nulens E et al. Serotypes and extended spectrum beta-lactam resistance in aminoglycoside resist- ant Pseudomonas aeruginosa isolates from two Belgian general hospitals: a seven year study. J Hosp Infect 1993; 24: $129-138$.

38. Cohen ML, Wong ES, Falkow S. Common R-plasmids in Staphylococcus aureus and Staphylococcus epidermidis during a nosocomial Staphylococcus aureus outbreak. Antimicrob Agents Chemother 1982; $21: 210-215$

39. Jaffe HW, Sweeney HM, Weinstein RA, Kabins SA, Nathan C, Cohen S. Structural and phenotypic varieties of gentamicin resistance plasmids in hospital strains of Staphylococcus aureus and coagulase-negative staphylococci. Antimicrob Agents Chemother 1982; 21 : 773-779. 